Volume: 12 Issue: 1 Year: 2015

\title{
"Taksim" in Traditional Turkish Classical Music within the context of reflection of gender on instrumental performance $^{1,2}$
}

\author{
Mümtaz Hakan Sakar ${ }^{3}$
}

\begin{abstract}
Improvisation skill is the sign of "mastership" for any musician regardless of the type of music he/she is involved in. Taksim, at the beginning of "fasil" phenomenon in Traditional Turkish Classical Music, is a type of improvisation which has specific rules and forms like as in Western Art Music and jazz. Therefore, "taksim", as an instrumental practice of which its' performer is called "creator", "master" and thus "musician", is seen as a male dominated practice. This study focuses on gender differences existing in the performance of taksim practice and aims to reveal how the practice is effected by gender culture. The data regarding the research are acquired through ethnographic observations and interviews and are conceptually analyzed.
\end{abstract}

Keywords: taksim; improvisation; woman; gender

\section{Introduction}

\section{Causes of women's secondary status within the context of gender conceptualization}

The concept of gender is approached as a symbolic structure in many academic studies. Multidisciplinary studies, through taking differences between nature and culture to the core, discuss whether differences between genders are originated from biology or culture. Whilst woman is seen closer to nature with her body and fertility, man is associated with creativity and technology. To put it in other words, woman is paired with nature while man is paired with culture. This approach is interpreted as the trivialization of nature, as transformation of balance of hierarchy in gender relations in favor of men.

\footnotetext{
1 The abstract and conclusion of this study had been presented in the 2nd National İzmir Music Symposium which was organized by Aegean University Turkish Music State Conservatory, in 2014.

2 The interviews transcriptions of this study made by Emre Zeytinci.

${ }^{3}$ Asist. Prof. (Phd)., Dokuz Eylül University Faculty of Buca Education, Fine Arts Education Department, Music Education Main Science, hakan.sakar@deu.edu.tr.
} 
Sakar, M. H. (2015). "Taksim" in Traditional Turkish Classical Music within the context of reflection of gender on instrumental performance. International Journal of Human Sciences, 12(1), 626-647. doi: 10.14687/ijhs.v12i1.3153

Dorothy Dinnerstein analyses the social system which accepts childrearing as duty of woman. Another theory comes up as the one that sees man as a dominant factor in the public sphere, and devalues women due to her role as a regenerator and a mother. Women, while bringing up their children, are also bound to function as "cultural transmitters" raising them with teaching about the meaning of being woman and man, besides their biological gender. For children of both genders, a woman is the first center of human body and the person who provides survival pleasure of social relations (Dinnerstein, Shepherd 1987). Chodorow, trying to bring a universal explanation to the reason why woman is in the secondary position says: "all through their lives, girls witness the devaluation of their identities while boys on the other side face with the challenge of proving their identities. Thus, as a result of this ongoing situation girls will continue to bow and boys will continue humiliating girls. (cit. Haviland 2002:187-188). Similarly, Rosaldo puts forward regeneration as the reason of woman's being in the secondary status. According to him, cultural systems tend to see domestic activities as invaluable, but the male activities, identified with public space, as valuable (cit. Özbudun \& Şafak, 2005). On the other side, Beauvoir links the same problem to Western tradition of thinking in binary oppositions. According to him, thoughts and symbols related to woman are multifarious. In every culture, woman is identified with what the culture has underrated i.e. clean-unclean, active-passive etc. (Beauvoir, 1993).

In mainstream disciplines of sociology and anthropology, duties and activities attributed to gender by that culture are explained with the concept of "role". The concept of role was first claimed in 1930s (Connell 1988: 56). It indicates the position of an individual in an organized social community, its responsibilities, privileges related to this position and the rules that channel individuals' social interactions in other positions. (Spence, 1985 - cit. Dökmen, 2004:16). According to Connel, gender roles are notions of scenario which is set socially for individual behavior, prelearned and performed subsequently. These roles replace the individual into social relations. Normative behaviors approved by society and - thus society's approval of correct behavior - but to punish wrong behaviors are still at the bottom. (Connell 1998: 58-79). Society has charged woman and man with different burdens and has diverse expectations from the. The realization of gender role takes place via teaching and having expectations from male and female individuals by society and different institutions of society. Social roles of women are explained by their natural features. Their domestic upbringing and caretaking responsibilities keep them away from social and cultural fields (Sakar, 2014:74). The "natural" unity of woman and child connects the social status of woman with home whereas man is attached to outside and to different fields of social life (such as economic, politic and cultural fields) (Kümbetoğlu, 2000/2: 241). 
Sakar, M. H. (2015). "Taksim" in Traditional Turkish Classical Music within the context of reflection of gender on instrumental performance. International Journal of Human Sciences, 12(1), 626-647. doi: 10.14687/ijhs.v12i1.3153

Besides anthropologic, sociological and psychological explanations, we can search for other main thinking systems that underlie the alienation and devaluation of woman in mythology. In most social environments, need for controlling a certain part of community is based on fear. This fear is hidden deep inside undoubtedly in public behaviors and systems of explanation. Looking from this perspective, this Western myth -a Jewish-Christian creation- holds some interesting parallelities together as well.

Woman (Eve) tempted (was culpable for undermining) the strength of man (Adam) by inviting him to eat her sacred fruit (spirit? body? knowledge? power?). Thus she unraveled the power of Man, and is responsible for life and nurturing (as punishment?) But she is tainted by blood without having to take another's life. Such power is feared, and must be usurped and controlled by Men, who blame Women for their original weakness (loss of control) and all subsequent losses of control. (Robertson 1987:230)

This is not the common explanation of this myth. But maybe, it might be assumptions internalized by people and institutions who need reasonings for those others who are forced to. But clearly explains the reasons why woman is not given leadership or allowed to rituals in Christian and Jewish traditions.

Another myth from Greek mythology explains the reasons why men should fear women and repress her. As can be understood, a woman is associated with evil. Especially, a beautiful woman, since she will seduce and mislead men for evil, which is very dangerous.

God Promote created the first human - man- out of fire he stole from the sky. The other Gods and Goddesses who gets angry with this created the first woman Pandora to punish the first human. Pandora, was the woman who spread all evil to the world and with the dowry box in her hand was created to punish man. (cit. Sevim 2005:19, Sakar:2014:101).

Thoughts on the subtexts of such myths which claim that woman should be kept under control are stimulating. Women develop their own musical culture even in patriarchal communities. These counter cultural attacks are just like keys for balance, resistance and social discourse. (Robertson 1984: 230.) 
Sakar, M. H. (2015). "Taksim" in Traditional Turkish Classical Music within the context of reflection of gender on instrumental performance. International Journal of Human Sciences, 12(1), 626-647. doi: 10.14687/ijhs.v12i1.3153

\section{Gender and Musical Activities}

Gender structure of a community reflects the social structure and ongoing regulations between men and women in a certain culture (see, Rosaldo, Lamphere, Koskoff). Margaret Mead claims that gender behaviors do not exist in nature but are shaped through human relations. Woman is given the duty of caretaker of a child due to her biologic nature. She is primarily positioned as a sexual partner and a baby sitter. Therefore, the overall unity between woman and music connects woman's sexual identity to performance of music.

According to Koskoff, women sexuality, as a counter cultural actuality, affects musical behavior in 3 ways: (1) Performance environments can create a general setting for an explicit sexual behavior. (2) Loss of women's sexuality can change her musical role and status. (3) Cultural beliefs about women's natural sexuality can cause restrictions on her musical activities. (Koskoff, 1989:6).

As a summary, Koskoff puts forward his ideas regarding woman's categorization within social structure whether heterosexually active or not, and on how the association is to be between her musical behavior and music. Within this context, heterosexually inactive women such as; young girls that deny their sexualities, old women, homosexuals and extraordinary women can play certain musical roles. Especially the old women can take place in music practice different from their own childhood and child rearing periods. Ernestine Friedl says that old women are able to acquire power and status differently from others, because the status of child rearing in mature women restrains her from many rituals. When women lose their sexual potential, she catches opportunity to turn the balance of her life upside down. (1975, cit. Koskoff, 1989:6)

Similarly Robertson (1984) says the performance and the meaning of music are the cornerstones of social order. In this sense, music has the potential to corroborate, limit or expand social awareness not only for women but also for men and children. Musical performance enables us to understand how people achieve their goals, how they turn their assumptions into action and how they challenge authority. To put it in other words, music and its performance contain social gender culture, power and complex community perceptions inside. Gender roles, social values and processes are included in the performance itself. Power and gender depend on assumptions related to nature of sexuality. In most of the known communities, social roles and situations of women before marriage are specified with religion to a great extent. Or at least, religion plays a dominant role in this determination. Majority of scholars working in gender studies explain the main reason as to explain men's domination, control and social status determination over women. According to these 
Sakar, M. H. (2015). "Taksim" in Traditional Turkish Classical Music within the context of reflection of gender on instrumental performance. International Journal of Human Sciences, 12(1), 626-647. doi: 10.14687/ijhs.v12i1.3153

scholars, religion has nothing to do with this although it is one of the major determinants in the subject of women and music. Some of related mythological, anthropological and sociological views have been shortly explained above.

\section{Women and Musical Activities}

Throughout centuries it was believed that women were banned from singing in public spaces with the thought that women voice distracts men and cause him sin (Robertson 1987:230). This example is parallel to the idea of prohibition of women in public space. That women myth which is believed to tempt men is not only limited to prevent women from singing in public space only. It prevents women to make music as well. As a result, woman was restricted from all forms of social interaction.

The case is not different from other eastern and western communities in Turkey. Especially in rural areas where religious motives are more dominant compared to cities, women's singing and playing instruments in public spaces are seen sinful from the viewpoint of religion and gender acculturation. To a great extent, this is valid for women living in big cities. The musical genres which women are in connection with are lullabies and requiems. The first one shouldn't be heard by any stranger men. Otherwise, it is believed that the sleeping baby would be visited by evil spirits. ${ }^{4}$ On the other side, requiems can be sung in public spaces. Other than these two music genres, women can only sing on their own while working at home or in the field or in indoors places during weddings and henna nights ${ }^{5}$. They can only sing at home for themselves provided that their voice is not loud enough to be heard from outside. A contradictory behavior would be seen disgraceful in that tradition.

Women are not allowed to perform any kind of music other than these exceptions in any place. Only the professional women (gypsies) are allowed to perform musical activity. However they are thought to be at lower status when compared to ordinary women, and religious rules are not binding for them. For such reasons these women are pushed away from communities they live in ${ }^{6}$.

In the cities, more women are able to deal with any kind of musical activity due to their higher access to education and economic independencies. For instance other than those who get music education at public schools, the number of girls who are supported to take private music lessons or

\footnotetext{
${ }^{4}$ see Reinhard:103, Herndon \& Ziegler:1990.

${ }_{6}^{5}$ Pre-wedding party.

${ }^{6}$ see Ziegler,1990:85.
} 
Sakar, M. H. (2015). "Taksim" in Traditional Turkish Classical Music within the context of reflection of gender on instrumental performance. International Journal of Human Sciences, 12(1), 626-647. doi: 10.14687/ijhs.v12i1.3153

following music classes in private music schools are relatively high. The number of women in amateur, local chorus is growing as well.

The restrictions before women's taking part in musical performance due to gender inequalities almost become invisible when they take part in "government supported institutions" such as music schools, conservatories, operas, state chorus and symphony. Their social status levels rise. Other than women who perform music in these officially accepted stages, there is a third category in which they perform "popular music" namely 'entertainment music'. Women performers of this category can be fully respected if they become famous and appear on TV. However, those at lower quality or less successful ones might be seen inferior and immortal. These women are mostly outcastes and oppressed in society. The traditional and conservative part of the society continues to live strictly.

According to the views regarding musical activity of women, they are considered to sing rather than playing instruments. Of course, in spite of these opposite views, there are some musical instruments which are seen acceptable according to mythical and cultural thoughts. Although classification of such musical instruments according to gender seems invalid today, they still exist in some professional and unprofessional contexts.

\section{Musical Instruments, Gender and Sex}

Although, there is an overall tendency to define musical instruments as sound producing devices which are used for making music, they are more than that. The musical instruments are not only mere products of local music cultures, but are also devices that change and redefine them within global cultural trends. A musical instrument movement without cultural boundaries is a fragile and problematic issue especially in "world music" example. (Dawe, 2003:274). Furthermore, musical instruments, just like in other musical phenomenon, symbolize and represent human and space.

When thinking from the perspective of cosmological systems of local communities and classifications of western specialists concerning the classifications of musical instruments, (such as string, wind and percussion), we can see that all these schemes either belong to uni-dimensional classifications specific to another culture or to a hegemonic or different system. Musical instruments are physical and metaphorical social structures and material objects. In fact, as sound producers they are "socially constructed to convey meaning" (Feld 1983:78, cit. Dawe, 2003:276). However, mistranslation, misrepresentation and deficiency clearly exist in such systems which replace "old instruments into new contexts" (Dawe, 2003:281). 
Sakar, M. H. (2015). "Taksim" in Traditional Turkish Classical Music within the context of reflection of gender on instrumental performance. International Journal of Human Sciences, 12(1), 626-647. doi: 10.14687/ijhs.v12i1.3153

Gender classifications and restrictions regarding musical instruments have existed throughout centuries. For instance; Edwards states that middle-aged women were represented as performers of percussion, organ and especially the string instruments. Wind instruments were neither considered feminine nor appropriate during Renaissance. Since the 15th century, percussion instruments have started to be considered suitable for professional women (those who take part in ceremonies and dancers) only. The middle-aged women used to play string instruments such as; vielle, harp and lyre. (1991:17)

Kurt Sachs, in his book titled "The History of Musical Instruments", after describing instruments played by women and men, makes a Freudian comment and says: "The gender of performer and the shape of instruments depend on the person who plays it, at least interpretively. Instruments of women and men are considered as their own organs. The subsequent situation is the articulation of instrument to the object of fertilization. (Sachs, 1940:51, cit. Koskoff, 1987:4).

As seen in Sachs' example, musical instruments are described differently in different cultural and social settings. Nicholas Thomas, in his analysis on the exchange of material products both in colonial and post-colonial periods in Pacific region says: "What were objects produced to become, but what have they become? We generally consume items and attribute meanings to them. This way, we exploit them by reproducing within our own imagination.” Thomas continues by saying: "Material culture researches and museum studies which equalize identity of something with it are imperialist identification works." This is an issue of what objects were produced to become as "old instruments with new contexts, but what they have become. Such creative re-contextualization and the situation of genuine re-writing are theft of tangible properties. According to James Clifford, this "entanglement" is a means of colonizing, owning and accumulating the objects of "outsiders" where collecting has long been a strategy for the deployment of a possessive self, culture and authenticity. (Clifford 1992, Vergo 1991, cit. Dawe 2003:282-283).

For example, in subculture of jazz, there are strong actual accepted norms related to instrument types and music genres such as masculine and feminine, among women and men colleagues. There have been dominant views regarding what type of instruments should be played according to genders throughout history. (Dahl 1984:36, cit. Hassinger,1987:196). Generally copper wind instruments and percussions were under the domination of men while string instruments and flute were identified with women. As Robertson transferred (1987), flute symbolizes phallus. Such gender categorizations, even today, refer to anatomical capacity and superior ability. However, in a 
Sakar, M. H. (2015). "Taksim" in Traditional Turkish Classical Music within the context of reflection of gender on instrumental performance. International Journal of Human Sciences, 12(1), 626-647. doi: 10.14687/ijhs.v12i1.3153

broader sense, it connotes social expectations as "appropriate women behavior". Surprisingly unsupportive statements of jazz subculture are demonstrated as the adequate motives that keep woman off from jazz stages (Hassinger: 197).

Although speculative, the gender classification of musical instruments is the result of community's wish to find itself within appropriate behavioral patterns. However, the positioning of women in musical performances is determined by male-dominant gender identity based cultures. Within this context, why does a woman playing drum or electro guitar in a rock band seem unusual? Or why was harp regarded as a female instrument throughout centuries? Similarly, why does traditional kemençe seemed appropriate for women? Is biology and physical situation of a drum player associated with the instrument itself? There are much more similar examples. In summary, classification of musical instruments according to gender is completely the extension of a culture identified with gender.

Gülten Yeğin, as a professional woman instrumentalist speaks from the point view of a gender based culture about instruments and gender classification:

In my opinion kemence (kemencha) is more appropriate for women with its aesthetic form. This doesn't mean that it is an instrument which shouldn't be played by men.'

\section{"Taksim" as an Instrumental Practice}

The practice of taksim is analyzed under two main titles. Its lyrical form is called gazel ${ }^{8}$ and according to oral resources it is called taksim when it is in the form of instrumental practice.

In traditional Turkish Classical Music, improvisation is considered male-dominant, since it is an instrumental form which requires creativity, and its performer is called the 'master'. As stated in theoretical approaches, women are associated with nature with their bodies and fertility; while men are associated with creativity and technology. Departing from this view, if taksim is creativity, it is seen as an appropriate behavior pattern for men. This view corresponds to Rosaldo's approach. As Rosaldo claims: Cultural systems tend to see female activities valueless and male activities valuable. Today, women are visible in government supported musical performance and education institutions

\footnotetext{
${ }^{7}$ The details of the interviews in this study are shown in the bibliography.

${ }^{8}$ Verbal improvisation.
} 
Sakar, M. H. (2015). "Taksim" in Traditional Turkish Classical Music within the context of reflection of gender on instrumental performance. International Journal of Human Sciences, 12(1), 626-647. doi: 10.14687/ijhs.v12i1.3153

such as TRT ${ }^{9}$, Classical Turkish Music State Chorus', Turkish Classical Music State Conservatories. Especially in Turkish Music State Conservatories, as in other music schools the number of female students is higher than males. A question arises as to why the number of female students is at minority in musical performance institutions of state although they are majority in conservatories. Before seeking for an answer to this question, the concept of improvisation and its types will be explained.

Etymologically, the meaning of taksim is partition. Onur Akdoğu defines the concept of taksim in his book titled "What is improvisation? How can it be made?" as follows:

In Turkish art music, taksim is called a type of music when solo instrument or solo singer dominates at the beginning, middle or rarely at the end of a 'fasil' by through improvisation. The literal meaning of taksim is "division". We don't know what type of music taksim means in Divan tradition. "In the $13^{\text {th }}$ century Divan music, Taksim was called making nehavt. In the $15^{\text {th }}$ century it was called demonstrating nehavt and maqam. The concept of taksim and its terminology has been coined into Traditional Art Music starting from the 1 $7^{\text {th }}$ century." (Akedoğu, 1989:2).

Besides Akdoğu, who describes "taksim" conceptually and functionally as "the mastery of instrument-sound" and "demonstrate maqam", Yetkin Özer underlines the action of improvisation.

In order to understand 'taksim', the only improvisation type in 'Divan' music, one needs to know and assimilate the meaning of improvisation. "Improvisation is the art of music recording without help of any text, draft or memory. (Apel HD, Improvisation-1, p.404). According to this definition, improvisation is supposed to be an instantly created an decomposed performance of performer which is independent of any musical type or form. However, despite this view there are examples both in international art music and divan music traditions that improvisation like composition can be pre-performance activity. When one remembers that W. A. Mozart's and J.S. Bach's fugue and L.V. Beethoven's sonata formed improvisations became popular in their own periods, it can be thought that there can be a planning process in the creation of improvisation which includes the assistance of "draft and memory. All these explanations show that we are not able to have pure improvisation. When we add historical process in music and think of an improvisation on a design, even though not all the improvisations done are the same, at some points, it is possible that the identical musical statements and motives appear. To this end, improvisation can be defined as a sort of imitation on the condition of keeping creativity. (Özer, 1986:1).

\footnotetext{
${ }_{9}$ Turkish Radio Television.
} 
Sakar, M. H. (2015). "Taksim" in Traditional Turkish Classical Music within the context of reflection of gender on instrumental performance. International Journal of Human Sciences, 12(1), 626-647. doi: 10.14687/ijhs.v12i1.3153

Stubbs defines the concept with the phenomenon of "improvisation". Taksim, with its different modes is an important component of Turkish classical repertoire. However, it cannot be played or sung like the compositions having regular forms and registers. Taksim are interpreted differently by every performer. Albert Lord (1060), defines the term taksim as a musical task which is "more than oral epic literature" different from printed and written instrumental and oral literature. Taksim is designed in the minds of performers and composed by itself in each performance. (1994:115).

Kaşif Demiröz's definition which approaches taksim as an independent form, is a substantial one more than being a contextual:

Taksim, as a free form in Turkish music is created completely through improvisation. It is a musical structure consisting of segments such as introduction, development and conclusion and reflects characteristics of maqam it is created in.

In order to better understand the subject, main types of taksim will shortly be explained. However, only the concept of "instrumental taksim" will be analyzed in detail for the purpose of this study. An improvisation made orally by human voice is called "oral taksim" (ghazel). Oral taksim started to lose ground since the first quarter of 20th century due to lack of gazelhan (ghazel readers). Thus, the name taksim became to be called for almost only for "instrumental improvisation". (Özer, 1986:10). It should be stated that oral taksim had existed long before its' instrumental version. "It wouldn't be wrong to say that 'unmeasured folk song' was the first form of oral taksim" (Akdoğu, 3). On the other hand, improvisations such as the azan and unmeasured folk songs such as bozlak, lament and maya which was in effect long before taksim can be said to have laid grounds for taksim.

Considering the instrument families, there are two types of taksim as "measured" and "unmeasured". "Measured taksim" is when other instruments accompany the improviser by playing the stronger sounds in unison with it. Although there is no maqam change in measured taksim, a certain degree of tension can be created through a change in strong sounds of mode. Such taksims are made in urban entertainment music mostly. On the other side, there is no specific rhythm in "unmeasured taksim". Other instruments accompany the improviser by playing one of the strong notes of the mode. This type of improvisation is present in mevlevi (sufi) music. In fact, this is very similar to "pedal tone" in western art music. Continuous bass party accompanies along the main improvised maqam. 
Sakar, M. H. (2015). "Taksim” in Traditional Turkish Classical Music within the context of reflection of gender on instrumental performance. International Journal of Human Sciences, 12(1), 626-647. doi: 10.14687/ijhs.v12i1.3153

When considered according to order of performance, taksim is segmented into: "initial taksim", "interlude taksim", "final taksim" and "transition taksim". These taksims take part at the beginning, in the middle and at the end of fasil respectively. It can be said that the initial taksim is being kept shorter than the interlude taksim today. However, traditionally, taksims exist only at the initial performance. (Özer,1986:15) In fact, in divan music which exist in Arab Music tradition, the conclusion taksim which was made to fill spaces at the end of records during fasil recordings is at the same position with introduction and transition taksims in this regard (Özer,1986:47). Thus, only the performance order is different. The transition taksim on the other side is a type used in today's fasil music. If there are more than one maqam in a fasil, transitions in between are blended to the following maqam through "transition taksim"

Other than the taksim types stated above, there is "fihrist taksim" type as well. This type of taksim which is made similar to types such as fihrist peşrev and fihrist saz semai, like kar-1 natık, transits to new maqam at the end of every sentence. Orders of maqams are not clear in this type. It requires competence since the orders of maqams are determined by the performer. It should be remembered that this type of taksim is the outcome of last 60-70 years.

After explaining the modes of traditional taksim, through interviews we made on the subject, we come to the decision that the context (intended use) is determinant in classification regarding taksim.

The place of usage and the aim of 'taksim' change its nature. Taksim puts forward the musical talent, accumulation and ability of an artist. It is not easy to 'taksim'. For instance; if you are going to 'taksim' in a certain mode of music, you should have played $30-40$ musical pieces of the same maqam. A buman who doesn't have the ability to compose cannot make 'taksim'. There should be creativity. 'Taksim' changes depending on the style of music you do. For instance, you are accompanying a singer (vocal): You should give bim a note before you start accompanying him. We call this the 'initial taksim'. Or if you are making taksim instead of 'pessrev' before a singer starts. That wouldn't be longer than 1-2 minutes. This is called 'initial taksim' as well. In addition to this, there is 'transition taksim' which means moving one musical maqam to another. Usually in maqam transitions we move from maqam hejaz to maqam usak or maqam hejaz to maqam kurdii hejaz kar. There can be other maqams in between as well. Thus, 'transition taksim' is normally longer than the 'initial taksim' since it involves the act of transition, in other words, modulation. Sometimes you pass to certain maqams very fast but sometimes it takes longer to make transition between maqams especially when there are 3 or 4 maqam to pass to since their sounds and structures are distant from each other. (Mabmut Bilki). 
Sakar, M. H. (2015). "Taksim” in Traditional Turkish Classical Music within the context of reflection of gender on instrumental performance. International Journal of Human Sciences, 12(1), 626-647. doi: 10.14687/ijhs.v12i1.3153

Apart from traditional and classic classifications of taksim, Kaşif Demiröz classifies taksim according to its intended use (where is which type of taksim made) and claims that taksim should be made accordingly.

If I am playing taksim in Classical Turkish Art Music, I consider the following music piece before doing. My taksim should call that piece. It should remind the following musical piece. In Mevlevi rituals, the initial taksim should remind the 'nat', so it should be kept long here. On the other side in TRT channel, the duration of taksim is determined according to time remaining during the broadcast. This type of taksim is called the "record taksim".

Nurdan Tezel Kaşif has similar thoughts on contextual (intentional) taksim, especially the "record taksim"

Think of a concert which should finish in a certain time. The vocal will start singing after the 'initial taksim' within the limits of this time. The best thing to be done here is to warm up the vocal to the musical piece through a short improvisation. Creativity doesn't become a part of this act here. Especially in professional settings in TRT channel there is a red light. You have to warm the vocal up within a given period (seconds). For this reason, in such taksims which should be done in limited time, the improviser is not able to show his musical talent due to the intended aim of taksim here. Of course the situation is different in settings. For instance the performers will have the chance to show their abilities and musical identities in a music band. Here, the aim of taksim will be different as well.

Nurdan Tezel's classification of taksim is twofold as "measured" and "unmeasured" Her description of taksim coincides with the conceptual descriptions stated above:

It should have introduction, development and conclusion segments like composition. The maqam is given clearly in the introduction, present maqam transits into other maqams in the development segment. The aim is to enliven the composition by adding different sentences. Like oral pieces, the first verse is introduction, second is chorus and the third is 'meyan'. Transition abilities of the 'taksimer' get very important here. Knowledge comes into play.

To sum up, the most apparent characteristic of the concept of taksim is its" "improvise" nature. Different from the "initial taksim" which is traditionally a part of fas1l, it has gained recognition regarding its place of use and hence the intention of use today. The best example for this is the type of taksim which is made in order to fill time in live performances and recordings called "record taksim". Another prominent factor is the determination of outline of taksim according to the following music piece. Besides, there is an emphasis that the creativity, theoretical knowledge and instrumental domination of performer of taksim are at highest level. Within this context, the 
Sakar, M. H. (2015). "Taksim" in Traditional Turkish Classical Music within the context of reflection of gender on instrumental performance. International Journal of Human Sciences, 12(1), 626-647. doi: 10.14687/ijhs.v12i1.3153

interviewees as the performer of taksim themselves agree that calling the creator of such a specific and original art as "masters" would not be an overstatement. According to Mahmut Bilki, "a musician who declines the making of taksim lacks something."

The interviewees are sharing the same opinion while answering the question why the practice of taksim is being neglected among today's musicians. Yetkin Özer's explanations towards “improvisation", which put emphasis on performer's making imitation instead of performing their own creativity and improvisation abilities, enlighten the subject. According to Nurdan Tezel, the modern education system which has been departing from the model of "master - apprentice" is the main reason of this problem.

Until a certain period, music notes weren't known and used much. Only the repertoire is being memorized. It gets more difficult to taksim once you get used to music notes. Taksim is not about imitating what we listen to. Not every improvisation is telling the core of that maqam. There should be a strict distinction. Extemporization is one thing, taksim is another thing. Giving maqam is a extemporization as well but taksim is the main thing that reveals the musical identity of the performer. So, I don't believe that everybody play taksim.

\section{Delegation of Instruments in the Practice of Improvisation}

Among the musical parameters regarding delegation of instruments in taksim, the "ideal sound" becomes prominent. The principle element on "ideal sound" is about choosing the correct instrument for correct maqam of music in order to give the intended feeling. Besides, due to musical speed concept, that is tempo, the agility of the instrument and vocalization ability cannot be neglected.

According to Mahmut Bilki, theoretically speaking, taksim can be made with every kind of instrument. However, choosing the right instrument for the right maqam needs specific attention.

Taksim can be made with every instrument. I, as a performer always choose the most appropriate maqam for my instrument. For instance, the hejaz kar maqam is played by 'kanun' (zither) perfectly. Pitch is another thing to consider. Not every instrument can be played in every pitch. A tambour player cannot taksim in hejaz kar maqam from a lower pitch. He can't get the required sound from the instrument. Likenise, you cannot play acemasiran maqam with oud. No, you can't. The conductor is the one to choose the most appropriate instruments for each maqam. For instance segah, saba and hejaz. maqams are played best with reed flute. Kurdili hejaz, kar and nibavend maqams are played well with kanun. Such maqams sound good. Taksim impresses more when played with string and 
Sakar, M. H. (2015). "Taksim" in Traditional Turkish Classical Music within the context of reflection of gender on instrumental performance. International Journal of Human Sciences, 12(1), 626-647. doi: 10.14687/ijhs.v12i1.3153

wind instruments. The determinant factors here would be the form and the maqam. Fasil music can be eagered when taksims are played with certain instruments. For instance, I would taksim with oud in karcihar or usak fasil. I would taksim with zither or tanbour while playing in kurdili hejaz, kar maqam and with kemencha while playing in surinak maqam. These instruments give he intended sounds better than others here.

According to N. Tezel, appointment of instruments in taksim is about the sound limit of the instrument and the ability to give modal effect. It is not about the lissomness of the instrument. Kaşif Demiröz agrees with this view. Gülten Yeğin, a 'classic kemençe' (kemancha) player at TRT Izmir channel brings performance and lissomness of instruments to the fore.

While saba and segah maqams mostly prefer reed flute taksims since their sounds are assimilated with religious feelings, kurdili hejaz kar is played with qither. (K. Demiröz)

The agility is about the performance of instrument. Agility can not be made with every kind of instrument. For instance, you can play fast passages and motives with kanun but it is not possible to do with kemence (kemancha). (G. Yeğin)

\section{Femininity and "Taksim"}

As it is put forward in the introduction of this paper, the determinant factor on music and women's musical activities is the gender enculturation, namely the patriarchy. When concepts such as taksim, mastership and musicianship are associated with the phenomenon of woman, the people we interviewed, regardless of their gender, consciously or not made reference to terms related to gender enculturation such as biologic differences, religion, patriarchy, role and statute.

Demiröz, attributes the reasons related to historical invisibility of women as an individual who was shaped with the point view of a society with ascribed culture, in music to gender roles. The main distinction here is between public space and private space. As said above in the introduction, the view which relates the social position of women with home and men to other fields of social life (economic, politic and cultural fields) is still valid (Kümbetoğlu, 2000/2: 241).

Men are more extrovert as women are more domestic. In patriarchal society women haven't been positioned as a musical performer who earns money through playing instruments. Under this mentality which reigned for more than 20 - 30 years, men and women had their own duties in life. Men would go out to earn money. Women would stay at bome and do the housework. Women wouldn't even imagine playing a musical instrument in that period. Whoever 
Sakar, M. H. (2015). "Taksim" in Traditional Turkish Classical Music within the context of reflection of gender on instrumental performance. International Journal of Human Sciences, 12(1), 626-647. doi: 10.14687/ijhs.v12i1.3153

goes outside would make the money. Men would do that in this setting. This was the main reason why women who performs music or improvises well were at minority. According to me, women's introversion was the reason of their invisibility in music.

Mahmut Bilki states that although there are very few women instrument players in traditional Turkish music the number of lyric writers and composers are higher than western countries. On the other hand, he thinks that women are associated with singing instead of playing instruments, and Bilki associates this invisibility of women in music activities to religion.

Going back to 19th century, we see that women were not involved in instrument playing as well. Turkish classical music was manifested as a masculine art. Women were at the second plan even in instrument playing. They preferred to be songwriters and composers instead. For instance; there are more women songwriters and composers than west, in our music tradition. Women started to play instruments after Tanzimat reform era. For example, danghters of those families living in luxury chattels used to play ode. Of course the religious faith is determinant here. Most of the previous singers used to be non-Muslims. There was almost not any woman before Safiye Ayla. All those Mermaid Eftelya and others were all non-Muslims. They used to be more comfortable while performing music. That was of course the extension of religious beliefs. The revolution started after the 19th century, with the influence of Tanzimat reform era. The bondswoman in the Harem room were given music education so as to make them more intellectual. Besides male teachers, servants such as Dilhayat gave music education to the bondswomen and mistresses in the palace because they had to be intellectual enough to be able to become wife to the Sultan.

Mahmut Bilki doesn't agree with distinction between sexes in any field including music. He remembers masters such as Veciha Deryal, Nursal Ünsal Birtek with respect. However, considering the subject of women's invisibility in music he sees gender and biological differences as reasons. This certainly is what feminist epistemology disagrees with:

You must have heard the name of zither artist Veciha Deryal. She was a virtuoso. We have such musicians in our bistory as well. Like Nursal Ünsal. However, I have to say that maybe because of the intensity of their daily duties, women didn't pay enough attention to musical activities. They didn't improve themselves. Although there were several women musicians, they weren't as perfect as virtuoso. It was the same in the West. All great violin virtuosos were male because women were busy looking after their children... So, women didn't have enough time to get involved in the action through its details as much as men did. The women weren't ambitious enough to improve her in music. Both genders were used to their roles. Women couldn't expose themselves since all their actions were controlled by men. Their roles were set by men. Women were always invisible. They couldn't make their voices heard. But somehow, the number 
Sakar, M. H. (2015). "Taksim" in Traditional Turkish Classical Music within the context of reflection of gender on instrumental performance. International Journal of Human Sciences, 12(1), 626-647. doi: 10.14687/ijhs.v12i1.3153

of girls was higher than boys in the conservatory. But this didn't help them become visible. Were they told to stop? Have anybody told them not to play instruments? However, the women were taught to marry and settle down or to find a guaranteed job and raise their children. This was what happened at that age.

Nurdan Tezel like Mahmut Bilki claims that women prefer singing rather than playing instruments and explains the reasons as follows:

In my opinion, women, rather than playing instruments, are more interested in singing. Playing an instrument is a difficult thing. Maybe they find it irrational to practice in a room for 7 hours nonstop. That needs a lot of sacrifice and love. I myself as an instrument player, don't really understand why women wouldn't prefer playing instruments.

Gülten Yeğin shares same ideas with Nurdan Tezel and Mahmut Bilki. Her views below on the thoughts of women who get stuck between professional and private life reveals difficulties she faces:

Sometimes I wish there was cloning or teleportation in reality. Wish there were 4 Gültens. One of them would be a bousewife, one would be a mother, one would go to work and the last one would be Gülten only because it is no easy to be yourself. You cannot spare time for yourselves. I am an obsessive, stubborn person. My obstinence is about life. I want everything to be in order in my house. I know some women who don't even care about their homes. They don't cook or iron clothes. There are some friends who are like that, but since I'm not that kind of person I want to be everywhere. However, I'm not sure if I made a mistake or not, I couldn't set balance between my danghter and my instrument. My instrument outweighed. Tours and concerts were my priority. I loved being on the stage. You forget everything when you are playing on the stage. I don't see anything but the strings of my instrument as soon as I start playing. If they ask me the best thing I enjoyed in my life, I would say playing my instrument on the stage. On the other side, unfortunately, you have a lot of problems with your children. Because children understand. She knew that I gave more importance to my instrument and my job.

Within this context she thinks men are more advantageous than women in professional life. Men are able to distinguish from women since they leave more time to their jobs. However, she points out that biological differences are insignificant in the subject "women and music"

My daughter didn't allow me to play at home for many years. She still doesn't like me play near her. Whenever I took my instrument and start playing, she would lay flat on purpose so that I would stop my instrument and show her attention. She was very jealous of my instrument. She was seeing it like her sister or brother. Men don't have such 
Sakar, M. H. (2015). "Taksim" in Traditional Turkish Classical Music within the context of reflection of gender on instrumental performance. International Journal of Human Sciences, 12(1), 626-647. doi: 10.14687/ijhs.v12i1.3153

problems. There is nobody to behave him capriciously or tell him to cook at home. Men have more opportunities and time to practice at home. On the other side, I don't agree with biological restrictions before women's playing instrument. I can carry this instrument and play it like men. This is my job.

In light of the information obtained through interviews, it can be thought that factors such as gender culture, responsibilities of women within the context of gender (motherhood, households, etc.), phenomenon such as religion have negative effects on music (instrument playing) performances of women. However, it should be noted that the negatively affected factor in Gülten Yeğin's life due to gender culture and roles was her private life. She doesn't say anything about any negative effects on her music performance. Although her professional life could have been affected indirectly, it cannot be ignored that many well educated female musicians, who are aware of such effects, ignore their professional lives in order to leave space for privileged private factors such as their family life.

\section{Gender as a cause of cultural identification and its appearances in taksim practice}

In the interviews that are conducted, we tried to look for clues regarding what components highlight the identity of woman in taksim pratical. Nurdan Tezel maintains a clears division between man and woman about execution/performance and thus on identity. However, right here, she opens a distinctive spot for her teacher Nursal Ünsal Birtek. She advances her superiority in creativity.

Of course there are men women who play instrument and taksim in their own ways. To be honest, I know only one person in this world who improvises perfectly. And she is by coincidence a woman. "Nursal Ünsal Birtek". Why her? Because you can never guess her next sentence while playing. Each taksim she makes is like a secret. She surprises you in every note she plays. She makes her instrument speak. She has a superior talent of creativity. I haven't seen anybody that can make such beautiful tones from an instrument. To me, this is a god given talent. She plays stronger than any male player. She uses every inch of her string. Nursal Ünsal doesn't have the concern of agility which is carried by most male musicians. All male musicians say that they play the fastest. On the other side, Nursal Unsal keeps very calm on this issue. But when it comes to playing, she plays faster than any male musicians. She knows what to do and where to do it. I've never seen this in any men. She knows how to speak slowly or fast. She improvises so beautifully that no one gets bored listening to her. I was always very curious about her next sentence but never was able to guess. I don't think there will be anybody like her anymore. I listened to all her taksims and have never seen anyone like ber in my life. 
Sakar, M. H. (2015). "Taksim" in Traditional Turkish Classical Music within the context of reflection of gender on instrumental performance. International Journal of Human Sciences, 12(1), 626-647. doi: 10.14687/ijhs.v12i1.3153

Nurdan Tezel's thought on "agility concern" in male performance and taksim can be seen as an appearance regarding identity in music context where male ethnicity dominates. This reminds the statement of Chodorow, where he says "Men face with the problem of proving their identities throughout their lives." Thus, agility in performance is accepted to be both the proof of male identity and the habitus of male ethnicity here.

Gülten Yeğin agrees with Nurdan Tezel's determination regarding the agility habitus which is a highly seen musical behavior which is adopted by male musicians in practice of taksim. She further claims that this behavior is regarded as a sign of mastery among male musicians and so lack of this behavior in certain male musicians might label them "incapable"

He was right saying that. There is a misdetection in our music. In Turkish music tradition they call you master if you play your instrument fast and "incapable" if you cannot. This is very wrong. Emotions should be considered before speed. In my opinion, a performance should both have speed and emotion depending on the instrument being played.

On the other side, Gülten Yeğin agrees with Tezel's view on performance differences between men and women. Yeğin while sharing her thought - although she is a woman herself- reflects Beauvoir's discourse on thinking with binary oppositions which is to say negative things are associated with women while positives are associated with men. As can be understood from Nursal Ünsal Birtek's descriptions regarding her characteristics and identity, Birtek, as with every individual, rises as a woman who is capable of negotiating her identity in volatile contexts, yet with identity of "androgyn" quality overall. Yeğin, while describing Birtek's musical identity says that she was "masculine" with her agility and the tonality of her instrument but "feminine" in her instrumental performance.

That was opposite to her personality. She was like a man when she was outside but emotional in her musical performance. Her music was so good. We are talking about a very special woman. Sometimes she would behave like a man but sometimes she would be a pure lady. On the other hand, she changes completely when she puts on make-up. She wouldn't put on make-up in her daily life. But when she does, she would become a beanty queen. She was a very interesting personality. I don't think there will ever be such a unique person anymore. She was a very special person.

Gülten Yeğin, as Nurdan Tezel does, underlines a definite feature regarding gender based differences of the practice of taksim. She brings woman ethnicity to the fore. She justifies the 
Sakar, M. H. (2015). "Taksim" in Traditional Turkish Classical Music within the context of reflection of gender on instrumental performance. International Journal of Human Sciences, 12(1), 626-647. doi: 10.14687/ijhs.v12i1.3153

thought of sensuality that gender culture seems appropriate for women while saying women, compared to men, give priority to emotions rather than agility during taksim performance. Accordingly, the formulation of gender is formed as follows: "men: agility, rigidity, not crying' 'women: emotions, tenderness, crying".

Women sensuality is very important. For instance my friends here tell me "Gülten, you are making us cry". Perhaps because they are woman. A male instrument player would pay attention to many details while listening to me playing. But it's different when the audience is female. Perhaps, we women are thinking more emotion based.

Furthermore, shedding light on the shaping of her music identity, Mahmut Bilki - about Nursal Ünsal Birtek- asserts his views regarding the reasons of her androgynic-self and his perspectives about the shaping of her musician identity. Carol Robertson claims that gender system in an ascribed culture can be considered as a prestige structure in itself. In all known societies, male performances are accepted as more valuable and prestigious. Furthermore, prestige loss of a man seems equivalent to feminine behavior. Robertson says: "Perhaps the most elusive and most significant motivator of human interaction, meanings and performances. In many societies, including those in the West, women's musical activities, genres, instruments and performance efforts are frequently considered by both men and women to be amateurish, unimportant or they are simply dismissed as not music. (1984:451, Koskoff:14-15) Bilki, even though showing respect to Birtek, displays parallelisms to Robertson's in his descriptions that he sees positive about her in his analogy "like a man".

She started her music carrier when she was a kid. She was a very talented girl. She came up through the ranks. She reads notes and plays, whereas in our society it is very difficult for gypsies to reach musicality. Her story is very interesting. She didn't have any education. She entered in certain societies under the influence of her father. She became a student of an amateur, Sabri Akçagöz and played in several weddings. She started playing violin when she was 1213 years old. Then, she passed the examination of Ankara radio at her early age. There weren't any female instrument players or performers at that time. She had the talent. She was extremely beautiful when she was young. She would change too much when she put on make-up. She would speak very well but would talk dirty when appropriate. She was like a man. She would drink like a man. She improved herself very well in the hands of great Turkish music masters like Cevdet Cağla and Mesut Cemil. She started working in Istanbul radio and gained incredible musicality in a short period. Mesut Cemil made her the master violinist. There is no second Nursal in this world. 
Sakar, M. H. (2015). "Taksim" in Traditional Turkish Classical Music within the context of reflection of gender on instrumental performance. International Journal of Human Sciences, 12(1), 626-647. doi: 10.14687/ijhs.v12i1.3153

She would taksim wonderfully. Her dominance over her instrument, her sound and processing melodies were like male performers. Music is more likely, as I understood, the art of men's telling their love to women. Not the opposite. When you look at our own songs you don't think that they can be played by women musicians. Because women are so kinder and elegant that brings your mind milder melodies. This elegance is revealed through vocals. Instrument sounds don't reveal any signs of gender" Or perhaps, there is this: since we haven't seen women performing like that, we say "performer like a man". This is how I interpret [the situation]. If only women would bring out performers like this. For example, we would call this is a man.

\section{Conclusion}

The main determinant in women's music life and their taking part in musical activities is the gender acculturation. This statement is valid for all women no matter living in the city or country, amateur or professional. The women which are outside the gender roles and expectations of any society are labeled as low status and "marjinal".

Gender classifications regarding musical instruments have been carried out since the antiquity. However, this cultural classification is artificial. This situation, as an effort to attach different meanings to this objectivity, exists in music and all the cultures related to it. However, it might have lost its' previous effect ever since women started to take part in music education.

Taksim is perceived as an instrumental form in Traditional Turkish Music. Instrument playing performance is accepted to be a "male-dominant" activity. However, although women have proved their abilities and talents in instrument playing, they may choose not to take part in musical activities in order to be able to better fulfil their gender roles (mother, wife) that are expected from them.

Delegation of instruments in the practice of taksim is determined according to instruments' performance in conveying the intended feelings in music. In other words "the ideal tone" is what is searched for. In this sense, seemingly, delegation by gender remains in secondary status. This classification type can be valid for instruments which are seen as "appropriate for women" (for instance klasik kemence (classical kemencha)). What men considers while performing taksim is "the agility", which represent their "male identity and virtuosity". However, as for women "sensuality" is at priority. Women consider "sensuality" and "agility" as equal importance. This is the expectation of social gender culture from sexes. Men are associated to "rigidity and technology" while women are associated to "fragility, sensitivity and nature". 
Sakar, M. H. (2015). "Taksim" in Traditional Turkish Classical Music within the context of reflection of gender on instrumental performance. International Journal of Human Sciences, 12(1), 626-647. doi: 10.14687/ijhs.v12i1.3153

Nursal Ünsal Birtek, is accepted as a "master". She was coded as "masculine" due to her musician identity, background, self-confidence and behaviours. This can be seen as an effort to her non sexualization. However, describing her music as "masculine" can also be seen as trivialization of her musical performance. On the other hand, she attracts extra attention due to her femininity.

\section{References}

Akdoğu, O. (1989). Taksim Nedir? Nasıl Yapılır?, İzmir.

Beauvoir, S. (1993). Kadin: İkinci Cins, 8. Basım, İstanbul: Payel

Connell, R.W. (1998). Toplumsal Cinsiyet ve İktidar, Çev: Cem Soydemir, İstanbul: Ayrıntı.

Dökmen Z. Y. (2004). Toplumsal Cinsiyet: Sosyal Psikolojik Açılamalar, İstanbul: Sistem.

Haviland, W. (2002). Kültürel Antropoloji, Çev: Hüsamettin İnanç ve Seda Çiftçi, İstanbul: Kaknüs.

Hassinger, J.(1987). Close Harmony: Early Jazz Styles in the Music of the New Orleans Boswell Sisters, Women and Music in Cross-Cultural Perspective, pp.195-202, Chicago: University of Illinois Press.

Hornbostel, E.\&Sachs, K. (1992). Classification of Musical Instruments, Ethnomusicology: an Introduction, Helen Myers (Ed.), pp. 444-461, London: The Macmillian Press.

Kümbetoğlu, B. (2000). Toplumsal Cinsiyet ve Antropoloji, Folklor/Edebiyat Dergisi, Sosyal Antropoloji Özel Sayısi, Ankara:Ürün.

Özer, Y. (1986). Geleneksel Türk Sanat Musıkisinde Taksim, Yayımlanmamış Yüksek Lisans Tezi, Dokuz Eylül Üniversitesi Güzel Sanatlar Fakültesi, Müzik Bilimleri Bölümü, İzmir.

Özbudun, S. ve Şafak, B. (2005). Antropoloji: Kuramlar/Kuramcular, Ankara: Dipnot.

Robertson, C. (1987). Power and Gender in the Musical Experiences of Women, Ellen Koskoff (ed.), Women in Music in Cross-Cultural Perspective, pp. 225-244, New York: University of Illinois Press.

Reihnard, U. (1990). The Veils are Liftes. Music of Turkish Women. Music, Gender and Culture, Marcia Herndon and Susanne Ziegler (Eds.), pp. 101-115, Wilhelmshaven: Florian Noetzel Verlag.

Sakar, M. H. (2014). Rock ve Ö₹lem Tekin. Gece Kitaplığ1, Ankara.

Sevim, A. (2005). Feminizm, İstanbul: İnsan.

Shepherd, J. (1987). Music and Male Hegemony, Music and Society: The Politics of Composition, Performance and Reception, Richard Leppert and Susan McClary (Eds.), Cambridge University Press.

Stubbs, F.W. (1994). The Art and Science of Taksim: An Empirical Analysis of Traditional Improvisation from 20 th Century Istanbul, (Doctor of Philosophy Dissertation, Wesleyan University, USA).

Ziegler, S. (1990). Gender-Specific Traditional Wedding Music in Southwestern Turkey, Music, Gender and Culture, Max Peter Baumann and Ulrich Wegner (Eds.), Wilhelmshaven: Florian Noetzel Verlag, 
Sakar, M. H. (2015). "Taksim" in Traditional Turkish Classical Music within the context of reflection of gender on instrumental performance. International Journal of Human Sciences, 12(1), 626-647. doi: 10.14687/ijhs.v12i1.3153

\section{Interviews}

Aydın, Erkan, (2014). Interview with Erkan Aydın, 27/03/2014, Ege Univ. TMDK., İzmir.

Bilki, Mahmut, (2014). Interview with Mahmut Bilki, 08/05/2014, TRT İzmir Müdürlügüu, İzmir.

Demiröz, Kaşif, (2014). Interview with Kaşif Demiröz, 03/04/2014, Ege Univ. TMDK. İzmir.

Tezel, Nurdan, (2014). Interview with Nurdan Tezel, 03/04/2014, Ege Univ. TMDK. İzmir.

Yeğin, Gülten, (2014). Interview with Gülten Yeğin, 22/05/2014, Ege Univ. TMDK. İzmir. 